\title{
Determinación cuantitativa de cal libre, por difracción de rayos $X$ en una matriz de cemento anhidro y desecado
}

\author{
Free lime quantitative determination \\ by $X$ ray diffraction, on anhydrous \\ and dried cement
}

J. L. SAGRERA, Dr. en Ciencias Químicas y Lcdo. en Ciencias de la Información IETCc/CSIC

Fecha de recepción: 28/IV/86

Serrano Galvache, s.n. 28033-Madrid/España

\section{RESUMEN}

En la fabricación de cementos, y dentro del control de su calidad, la determinación rápida del contenido de cal libre es un dato necesario.

Esta determinación, según normativa $\left({ }^{*}\right)$, debe hacerse usando la via química. Como método alternativo existe la técnica de difracción de rayos $X$ que, en pocos minutos, puede determinar el contenido de cal libre, sin posibles interferencias de otros compuestos. La medida del contenido se hace midiendo la altura de un pico del difractograma de rayos $X$ que, para cada caso, es privativo del compuesto que se quiere determinar.

En el presente artículo se trata de explicar, paso a paso, el procedimiento para determinar cuantitativamente el contenido de cal libre que existe en un cemento anhidro y desecado a $110^{\circ} \mathrm{C}$.

Para ello, se construye una curva de calibrado utilizando tres muestras sintéticas preparadas en el laboratorio partiendo del cemento utilizado, al que se le añade el $1 \%, 3 \%$ y $5 \%$ en peso de OXIDO DE CALCIO preparado calcinando a $1.100^{\circ} \mathrm{C}$ durante dos horas CARBONATO DE CALCIO precipitado Merck. Dicha curva de calibrado permite conocer el contenido de cal libre, del cemento de partida, cuando el resultado obtenido por difracción de rayos $X$ se lleva a la curva patrón obtenida.

\begin{abstract}
SUMMARY
In manufactured cements, and concerning the quality control, the fast determination of the contents of free lime is a necessary step. The measurement of the content is made taking the net altitude of one peak of the DRX which, on each case, is peculiar to the compound to be determined.

So, a calibrating curve is drawn, using there synthetic samples prepared with original cement with addition of $1 \%, 3 \%$ and $5 \%$ in weight of calcium oxide prepared fusing at $1.100^{\circ} \mathrm{C}$ for two hours a Merkc precipitate calcium carbonate. This calibrating curve allows to know the free lime content in original cement, when the results obtained by $X$ ray diffraction is carried to the calibrating curve.
\end{abstract}

\section{PREPARACION DE LAS MUESTRAS}

Se pesan tres muestras de 1,5600 gramos del cemento anhidro y desecado a $110^{\circ} \mathrm{C}$, del cual queremos conocer su contenido en cal libre y se le añade a cada una de las muestras 0,0156 gramos; 0,0468 gramos, y 0,0780 gramos de óxido de calcio, preparado

\section{THE PREPARATION OF THE SAMPLES}

Three samples of $1,5600 \mathrm{gr}$ made from anhydrous cement and dried at $110^{\circ} \mathrm{C}$, which free lime content is to be known, are weighed, and to each one of the samples it is added $0,0156,0,0468$ and $0,0780 \mathrm{gr}$ of calcium oxide, prepared from calcium carbonate; in this way

(*) Pliego de prescripciones técnicas generales para la recepción de cementos, 1975. Secretaría General Técnica del M.O.P. 
a partir de carbonato de calcio; de esta manera tendremos tres muestras denominadas $\mathrm{A}, \mathrm{B}$ y $\mathrm{C}$ con los contenidos en cal libre siguientes: we shall have three samples named $A, B$ and $C$ with the following free lime contents:

\begin{tabular}{|c|c|}
\hline $\begin{array}{c}\text { Muestras } \\
\text { (Samples) }\end{array}$ & $\begin{array}{c}\text { Contenido en cal libre } \\
\text { (Free lime content) }\end{array}$ \\
\hline $\mathrm{A}$ & $(\mathrm{x}+1) \%$ \\
$\mathrm{~B}$ & $(\mathrm{x}+3) \%$ \\
$\mathrm{C}$ & $(\mathrm{x}+5) \%$ \\
\hline
\end{tabular}

siendo, $\mathrm{X}$, la concentración de cal libre que tiene el cemento utilizado en nuestras mezclas y cuyo contenido es desconocido.

La homogeneización de cada una de las muestras (A, B y C) se lleva a cabo utilizando un molino vibratorio marca Specamill de la firma Specac (Kent, England) durante cinco minutos, utilizando un recipiente cilíndrico de CELOTEX de 48 milímetros de altura y 13 milímetros de diámetro interno, tapado en ambas bases con tapones de goma virgen, dentro del cual se introducen la muestra y tres bolas de acero de 8 milímetros de diámetro. Extraída la muestra del cilindro se prensa sobre el portamuestras rectangular que tiene el equipo compacto PHILIPS PW-1840.

\section{DIFRACTOGRAMA DE LAS MUESTRAS}

La determinacion del contenido de cal libre, en el cemento estudiado, se lleva a cabo

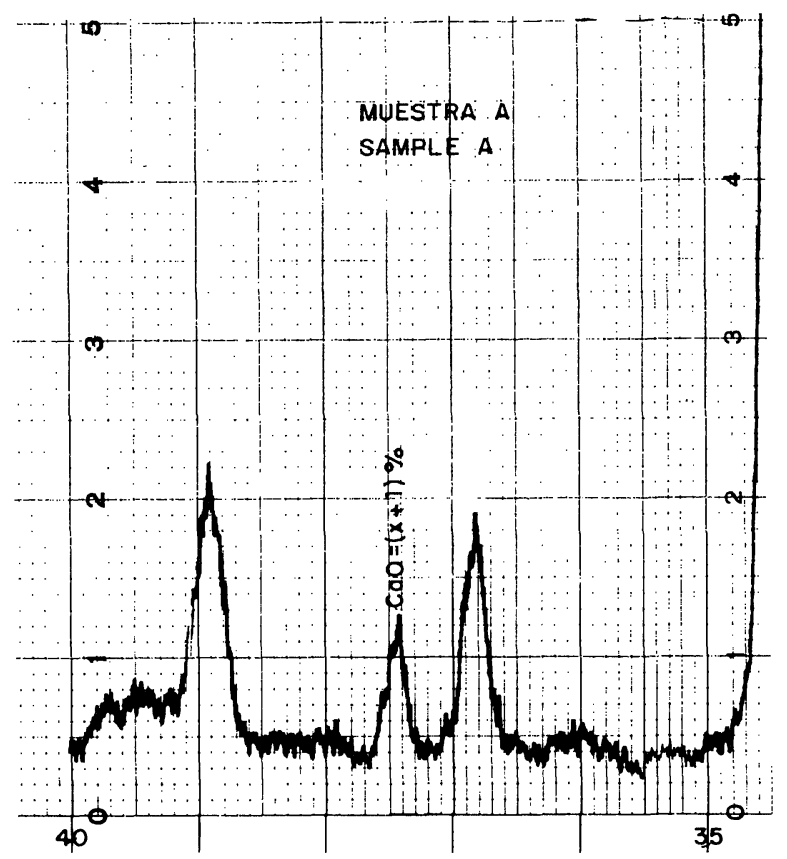

Fig. 1 being $X$ the free lime concentration that cement used in our admixtures has, and which content is unknown.

The homogeneousity of each sample (A, B and $C)$ is carried out using a "Specamill" vibrator of Specac firm (Kent, England) during five minutes, using a CELOTEX cylindrical receptacle of $48 \mathrm{~mm}$ height and an inside diameter of $13 \mathrm{~mm}$, its two bases closed with ruber plugs, within it the sample and three steel balls of $8 \mathrm{~mm}$ diameter are introduced. Taken the sample out from the cylinder, it is pressed on the rectangular sample holder, which is a part of the PHILIPS PW-1840 compact equipment.

\section{DIFRACTOGRAM OF THE SAMPLES}

The determination of the free lime content on the original cement is made by means of the

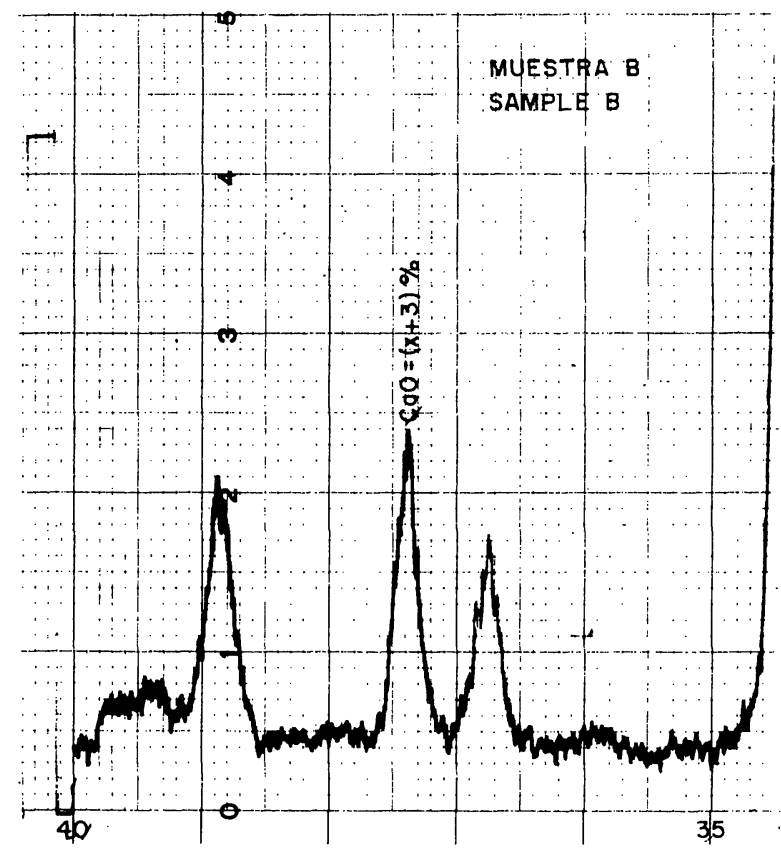

Fig. 2 


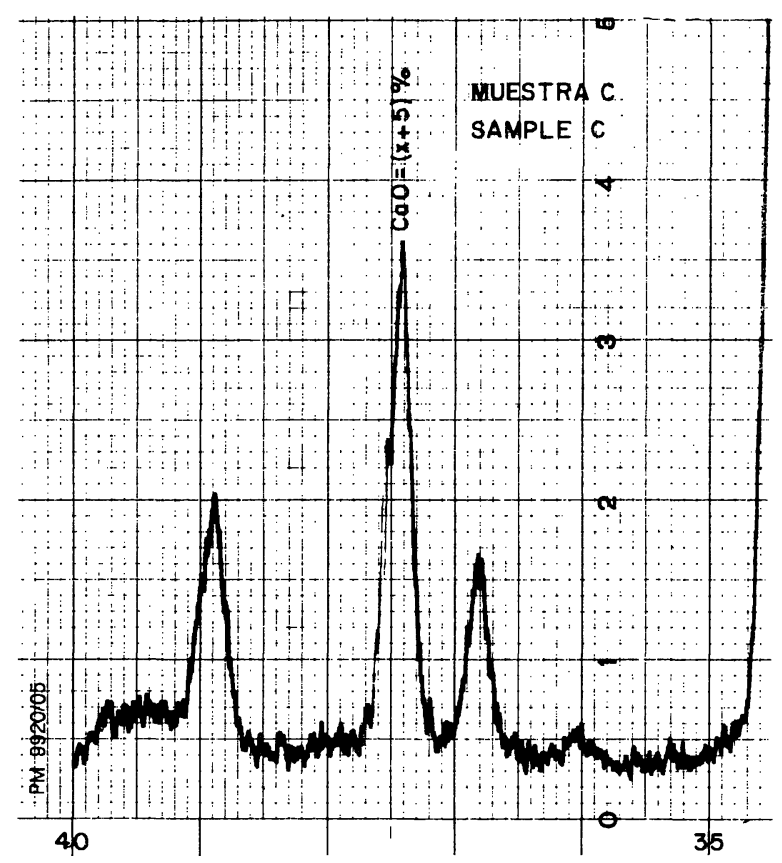

Fig. 3

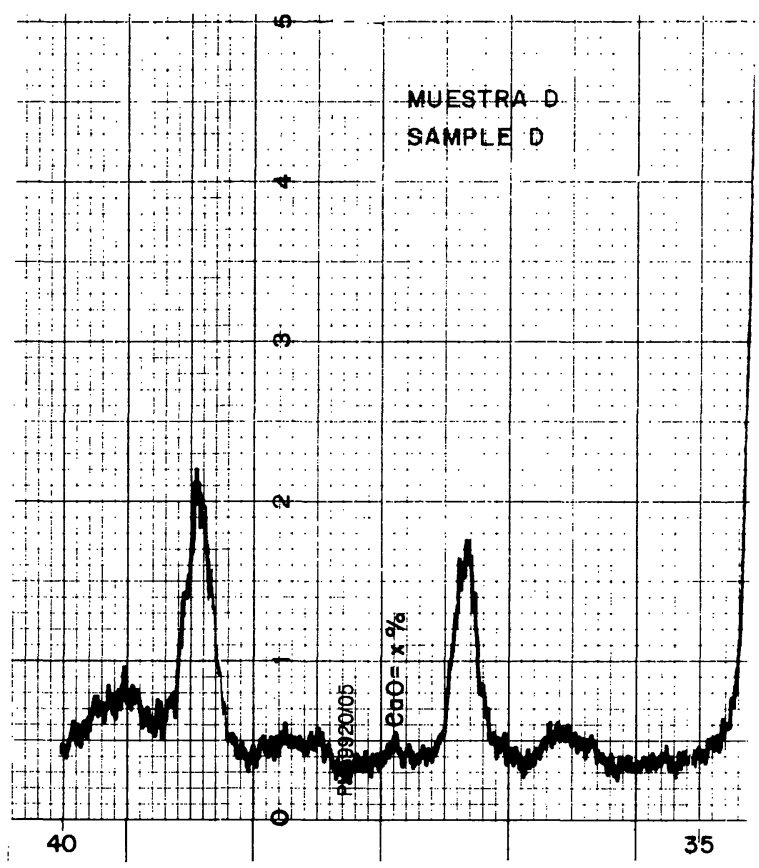

Fig. 4

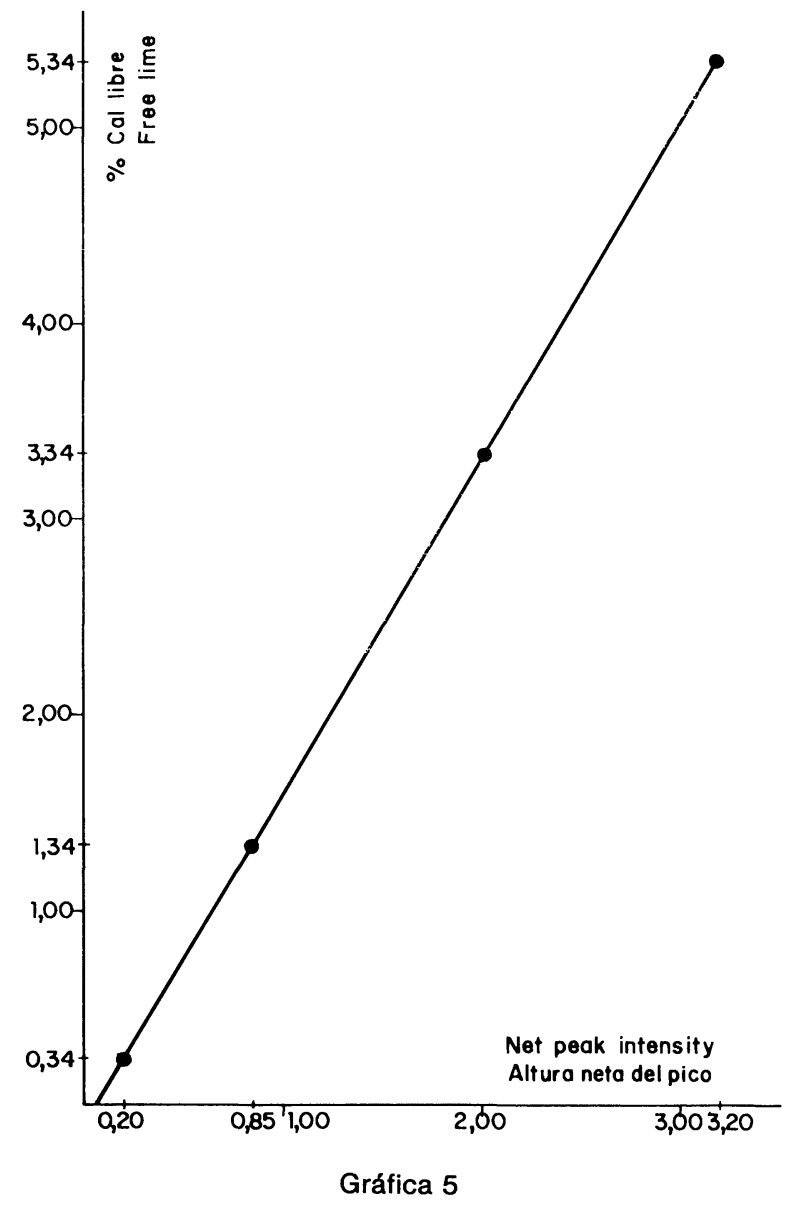

mediante los difractogramas de cada una de las muestras estudiadas. En dichos difractogramas, la medida de la altura neta del pico - de intensidad relativa 100 , del
DRX of each synthetic sample. On these DRX the measure of the net height of the peak -with relative intensity 100 , of the " $L Y M E$ SYN" crystalline compound- file 4-777 of the 
compuesto cristalino "LIME SYN"-, ficha número 4-777 del J.C.P.D.S. (*) (1983), es proporcional al contenido de cal libre presente en el cemento. El pico estudiado en nuestro caso tiene un valor angular $2 \theta$ igual a $37,36^{\circ}$. El valor neto de la altura de este pico se obtiene restando, de su altura total, la altura de su fondo (figuras 1, 2, 3 y 4) y Tabla 1.

\section{RESULTADOS OBTENIDOS}

El trazado de la curva de calibrado (gráfica 5) se hace llevando sobre ordenadas los tantos por ciento de cal libre en cada una de las muestras, que corresponden en abscisas con los valores de las aituras netas para cada caso. Sobre dicha curva de calibrado, y en los valores de abscisas, se toma el resultado de la altura neta correspondiente al pico de la cal libre del cemento - sin adición de cal- dicho punto tendrá una correspondencia en valor de ordenadas, que dará el contenido de cal libre en el cemento estudiado.
J.C.P.D.S. $\left.{ }^{\star}\right)(1983)$, is proportional to the content of free lime present in the cement. The peak studied in this case has $2 \theta$ angular value equal to $37,36^{\circ}$. The net height value of the peak is obtained substracting the background from the total height (figs. 1, 2, 3 and 4, and Table 1).

\section{RESULTS OBTAINED}

The drawing of the calibrating curve (fig. 5) is plotted carrying on ordinates the free lime percentages in each one of the samples which correspond in abscissas with the net heights for each case. On this calibrating curve, and in the values of the abscissas, the resuit of the net height corresponding to the free lime peak of the cement - without free lime addition - is taken. This point will have a correspondance in ordinate values, that will give the content of free lime in the original cement.

TABLA

\begin{tabular}{|l|c|c|c|c|}
\hline & $D$ & Muestra A & Muestra 8 & Muestra C \\
\hline $\begin{array}{l}\text { Contenido de CaO } \\
\text { (Content) }\end{array}$ & $(x)$ & $(x+1)$ & $(x+3)$ & $(x+5)$ \\
\hline $\begin{array}{l}\text { Altura total del pico } \\
\text { (Total hight of the peak) }\end{array}$ & 0,55 & 1,25 & 2,40 & 3,60 \\
\hline $\begin{array}{l}\text { Altura del fondo } \\
\text { (Background) }\end{array}$ & 0,35 & 0,40 & 0,40 & 0,40 \\
\hline $\begin{array}{l}\text { Altura neta } \\
\text { (Net height) }\end{array}$ & 0,20 & 0,85 & 2,00 & 3,20 \\
\hline
\end{tabular}

A partir de estos resultados, se pueden hacer las siguientes proporciones:
From these results it is possible to do the following proportions:

$$
\begin{aligned}
& (x+5) \% \mathrm{CaO} \\
& (x+3) \% \mathrm{CaO}
\end{aligned}
$$

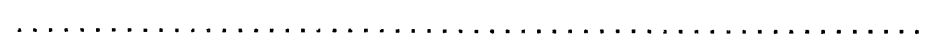

Resta:

$$
x_{1}=0,3333
$$

(Substraction)

$(x+5) \% \mathrm{CaO}$

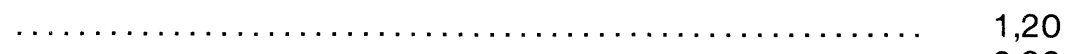

$(x+1) \% \mathrm{CaO}$

Resta

$$
4 \% \mathrm{CaO}
$$

(Substraction)

$$
\begin{aligned}
& x_{2} \\
& x_{2}=0,3404 \\
& (x+3) \% \mathrm{CaO} \\
& (x+1) \% \mathrm{CaO}
\end{aligned}
$$
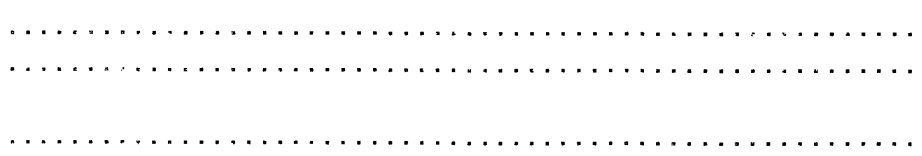

Resta

$$
2 \% \mathrm{CaO}
$$

(Substraction)

$$
x_{3}=0,3478
$$

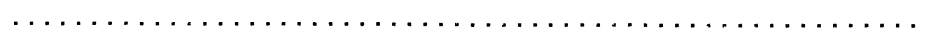

(*) Powder Diffraction File Inorganig Phases (1983) Joint Committee on Power Diffraction Standards-1601 Park Lane, Swarthmore, Pennsylvania 1981 - U.S.A

(*) Power Diffraction File Inorganic Phases (1983) Joint Committee on Power Diffraction Standards - 1601 Park Lane, Swarthmore, Pennsylvania 1981 - USA. 
Media aritmética de los tres valores: $X_{m}=0,3405$.

Luego el contenido de cal libre, en el cemento anhidro y desecado a $110^{\circ} \mathrm{C}$, es de $0,34 \%$.

Los valores de ordenadas de las muestras $A, B$ y $C$ serán respectivamente:
Arithmetic mean of the three values:

$X_{m}=0,3405$.

Therefore the free lime content in the anhidrous cement, dried at $110^{\circ} \mathrm{C}$, is of $0,34 \%$.

The ordinate values of the samples $A, B$ and $C$ will be respectively:

$$
\begin{aligned}
& A=0,34+1,00=1,34 \% \\
& B=0,34+3,00=3,34 \% \\
& C=0,34+5,00=5,34 \%
\end{aligned}
$$

que corresponden con los valores de abscisas siguientes:

which correspnd with the following abscisas:

$$
\begin{aligned}
& A=0,85 \\
& B=2,00 \\
& C=3,20 \\
& D=0,20 \text { (cemento sin adición de } \mathrm{CaO} \text { ) } \\
& \text { (cement without } \mathrm{CaO} \text { adaition). }
\end{aligned}
$$

Luego a partir de estos valores de abscisas y ordenadas se puede construir la curva de calibrado. Como normalmente en los cementos portland las fases y sus contenidos son parecidos puede decirse que la matriz de las muestras es también parecida y, por tanto, la curva de calibrado obtenida puede valer para determinar el contenido de cal libre en cualquier cemento portland.

Partiendo de dicha curva de calibrado, el tiempo estimado para hacer el difractograma que produce el pico de cal libre, entre valores de $2 \theta=35^{\circ}$ y $2 \theta=40^{\circ}$, es de 3,3 minutos. Sumando a este tiempo, el tiempo de prensar la muestra en el portamuestras y el tiempo necesario para medir la altura neta del pico, puede totalizarse un tiempo de cinco minutos.

Puede decirse que el método es rápido; y no destructivo, puesto que la muestra es recuperable y de pequeña cuantía ( 2 gramos).
Therefore from tinese values of abscissas and ordinates we can draw the calibrating curve. Usually the phases and contains in the portland cements are similar, therefore the free lime calibrating curve is useful for any portland cement.

Starting from this calibrating curve, the estimated time to make the DRX that the free lime peak produce between values of $2 \theta=35^{\circ}$ and $2 \theta=40^{\circ}$, is 3,3 minutes. Adding this time to the pressing time of the sample on the sample holder and the needed time to measure the net height of the peak, we could have five minutes time.

It could be said that the method is fast and not destructive, since the sample is recoverable and of little amount (2 gr). 